\title{
Analysis of Clean Water Needs Rural Community Based (A Case Study Hippam Campurrejo Makmur Bojonegoro)
}

\author{
Sulton Arrahman Ali, F.Rooslan Edy Santosa \\ Faculty of Civil Engineering Departments, Engineering Study Program \\ Narotama University Surabaya, Indonesia \\ Surabaya, Indonesia \\ sultonarrahmanali6@gmail.com, eddy.santosa@narotama.ac.id
}

\begin{abstract}
The problem of providing clean water is currently a special concern for both developed and developing countries. Indonesia as a developing country cannot be separated from the problem of providing clean water for its people. One of the main problems faced is the unavailability of clean water sources, the unequal distribution of clean water services, especially in rural areas and the existing clean water sources have not been utilized optimally.villageCampurrejo subdistrict BojonegoroBojonegoro Regency is in dire need of adequate clean water, because so far residents have had difficulty getting clean water, especially during the dry season, some residents only rely on water in old springs/wells without adequate facilities. The research objectives are, 1) to know the speed ofthe need for clean water in the village of Campurrejo sub-district Bojonegoro, Bojonegoro Regency tohi year 2031,2) What is the reservoir capacity needed to meet the need for clean water in 2031 ? Analysis of the calculation of population growth in the village Campurrejo subdistrict Bojonegoro the author uses the Geometric method. And it can be seen that the population in the village Campurrejo subdistrict Bojonegoro reached 6,829 people, and the water demand in 2031 according to the prediction of the population is 1,105 liters/second, the maximum daily needs is 1,326 liters/second, and the discharge at peak hours is 1,768 liters/second.And the demand for clean water in Campurrejo Village in 2031 according to the prediction of the number of HIPPAM customers is 1,623 liters/second, the maximum daily need is 1,948 liters/second, and water needs at peak hours are 2,567 liters/second. Prediction of the number of customers of HIPPAM "Campurrejo Makmur" in 2031 is 1298 SR The need for reservoir capacity to meet the needs of clean water in 2031 is 157 $\mathrm{m} 3$. Since the reservoir capacity is only $18 \mathrm{~m} 3$, it is necessary to add another $139 \mathrm{~m} 3$ to meet the needs of HIPPAM customers "Campurrejo Makmur"
\end{abstract}

Keywords: Clean Water Needs, Distribution, HIPPAM, Population

\section{Introduction}

Clean water is a source of natural ecosystems for human survival that is needed in a sustainable manner. Everyone's condition of the availability of clean water is a daily necessity in community activities in sufficient and suitable quantities. The need for clean water in the household, industrial, plantation sectors and other facilities. It will continue to grow along with the increasing number of population and in terms of the development sector in various fields. Then the problem arises that the number of clean water providers is small, so that water needs are not fulfilled.

This clean water supply system is planned so that residents can meet their water needs without having to bother taking them directly to water sources that are very difficult to reach. By paying attention to the location and the existing potential, it is hoped that the need for clean water in Campurrejo Village, Bojonegoro District, Bojonegoro Regency can be fulfilled as a whole.

The level of economic growth and the increasing number of residents, the available facilities need to be optimized both in terms of services and the provision of clean water facilities themselves. Therefore, a clean water distribution pipe network plan was made in Campurrejo Village which seeks to provide an effective and efficient clean water drainage system in order to improve services to the community, from the wellbore water source HIPPAM Campurrejo Makmur Bojonegoro,The clean water supply system must be able to provide sufficient air for the required needs. Requirements The drinking water supply system must consist of technical provisions: Raw water unit, production unit, distribution unit, and service unit.

To find out the estimated amount of clean water needs to be planned from population growth in the coming years, several methods are used, including arithmetic methods, geometric methods. To find out the estimated 
amount of clean water needs to be planned from population growth in the coming years, several methods are used, including arithmetic methods, geometric methods.

\section{a. Arithmetic Method}

This method is used when periodic data shows the number of additions that are relatively the same every year. This happens in cities with a relatively small area.

Formula: Arithmetic Method

Where:

$$
\begin{gathered}
\mathrm{Pn}=\mathrm{Pt}+\mathrm{Ka}^{*} \mathrm{X} \\
K a=\frac{(P t-P o)}{t-1}
\end{gathered}
$$

Pn $\quad=$ Total population in the next $\mathrm{n}$ years

$\mathrm{Pt} \quad=$ Total population at the end of the data year

Po = Total population at the beginning of the data year

$\mathrm{X}=$ Time lapse

$\mathrm{Ka}=$ Ratio of average population increase per year

$\mathrm{t}=$ Number of data minus one

\section{b. Geometric Method}

This method is used when the population data shows a rapid increase from time to time. This method is appropriate to be applied to the case of population growth in cities with high economic growth and rapid urban development.

Formula: Geometric Method

$$
\begin{gathered}
\mathrm{Pn}=\operatorname{Pt}(1+\mathrm{r})^{\mathrm{n}} \\
r=\left(\frac{P t}{P o}\right)^{(1 / t)}-1
\end{gathered}
$$

Where :

$$
\begin{array}{ll}
\mathrm{Pn} & =\text { Total population in the next } \mathrm{n} \text { years } \\
\mathrm{Pt} & =\text { Total population at the end of the data year } \\
\mathrm{Po} & =\text { Total population at the beginning of the data year } \\
\mathrm{n} & =\text { nth year }- \text { last year } \\
\mathrm{r} & =\text { Ratio of average population increase per year }
\end{array}
$$

\begin{tabular}{|c|c|c|c|c|c|}
\hline \multirow{4}{*}{ Description } & \multicolumn{5}{|c|}{$\begin{array}{c}\text { City Category Based on Population } \\
\text { (Soul) }\end{array}$} \\
\hline & $>1.000 .000$ & $\begin{array}{c}500.000 \\
1.000 .000\end{array}$ & $\begin{array}{c}100.000- \\
500.000\end{array}$ & $\begin{array}{l}20.000- \\
100.000\end{array}$ & $<20.000$ \\
\hline & City & City & City & City & Village \\
\hline & Metropolitan & Big & Medium & Small & \\
\hline 1 & 2 & 3 & 4 & 5 & 6 \\
\hline SR unit (I/o/hr) & 190 & 170 & 150 & 130 & 30 \\
\hline HUunit s (I/o/hr) & 30 & 30 & 30 & 30 & 30 \\
\hline Non Domestic Unit & $20-30$ & $20-30$ & $20-30$ & $20-30$ & $20-30$ \\
\hline Water Loss $(\%)$ & $20-30$ & $20-30$ & $20-30$ & $20-30$ & $20-30$ \\
\hline Maximum Day Factor & 1,1 & 1,1 & 1,1 & 1,1 & 1,1 \\
\hline Peak-Hour Factor Factor & 1,5 & 1,5 & 1,5 & 1,5 & 1,5 \\
\hline Number of Souls Per SR & 5 & 5 & 6 & 6 & 10 \\
\hline Number of Souls Per HU & 100 & 100 & 100 & $100-200$ & 100 \\
\hline Operating Hours & 24 & 24 & 24 & 24 & 24 \\
\hline Reservoir Volume (\%) & 20 & 20 & 20 & 20 & 20 \\
\hline SR : HU & $50: 80$ & $50: 80$ & $80 ; 20$ & $70 ; 30$ & $70 ; 30$ \\
\hline Service Coverage & 90 & 90 & 90 & 90 & 90 \\
\hline
\end{tabular}

\section{c. Domestic Water Supply Standards}

Domestic Water Supply Standards are determined by the number of domestic consumers who can be identified from existing population data. Standards for supplying domestic needs include drinking, bathing, cooking, and others.

Table 1. Clean Water Planning Criteria

Source: Planning Criteria of the Directorate General of Public Works Cipta Karya, 1996 
Domestic water needs for cities are divided into several categories, namely:

- City category I (Metropolitan)

- City category II (Big City)

- City category III (City Medium)

- City category IV (Small Town)

- City category V (Village)

\section{d. Non-Domestic Water Supply Standard}

Non-domestic water supply standards are determined by the number of non-domestic consumers which include facilities such as offices, health, industrial, commercial, public, and others.

Table 2. Non-Domestic Water Needs for Cities Category I, II, III, IV

\begin{tabular}{ccc}
\hline Sector & Unit & Value \\
\hline School & 10 & lt/student/day \\
Hospital & 200 & lt/bed/day \\
Public Health Center & 2000 & $1 \mathrm{l} /$ units/day \\
Mosque & 3000 & $1 \mathrm{t} /$ units/day \\
Market & 12000 & $1 \mathrm{t} / \mathrm{ha} /$ day \\
Hotel & 150 & $\mathrm{lt} / \mathrm{bed} /$ day \\
Industrial Area & $0,2-0,8$ & $\mathrm{lt} /$ second/day \\
Office & 10 & lt/person/day \\
\hline anning Criteria of the Directorate General of Public Works Cipta Karya, 1996
\end{tabular}

Table 3. Non-Domestic Water Needs for Category V (Village)

\begin{tabular}{ccc}
\hline Sector & Unit & Value \\
\hline School & 5 & $1 \mathrm{t} /$ student/day \\
Hospital & 200 & $1 \mathrm{t} / \mathrm{bed} /$ day \\
Public Health Center & 1200 & $1 \mathrm{t} /$ units/day \\
Mosque & 2000 & $\mathrm{lt} /$ units/day \\
Market & 10 & $1 \mathrm{t} / \mathrm{ha} /$ day \\
Industrial Area & 10 & $\mathrm{lt} / \mathrm{second} /$ day \\
\hline
\end{tabular}

Source: Planning Criteria of the Directorate General of Public Works Cipta Karya, 1996

Table 4. Non-Domestic Water Needs for Other Categories

\begin{tabular}{ccc}
\hline Sector & Unit & Value \\
\hline Airfield & 5 & $1 \mathrm{t} /$ Person/second \\
Harbor & 200 & $1 \mathrm{t} /$ Person/second \\
Bus Station & 1200 & $1 \mathrm{t} /$ Person/second \\
Industrial Area & 10 & $1 \mathrm{t} /$ Person/ha \\
\hline
\end{tabular}

Source: Planning Criteria of the Directorate General of Public Works Cipta Karya, 1996

To predict the development of non-domestic water needs, it is necessary to know the city development plan and its activities. If it is not known, then the prediction can be based on a population equivalent, where nondomestic consumers can be counted following the development of domestic water supply standards. Thus we need to know the type and number of future means or in other words we need to know: 1) Types and number of facilities currently available, this data is needed as a basis for calculating the estimated type and number of facilities in the future; 2) Estimated development of the type and number of facilities in the future. 


\section{Methodology}

\subsection{Workflow}

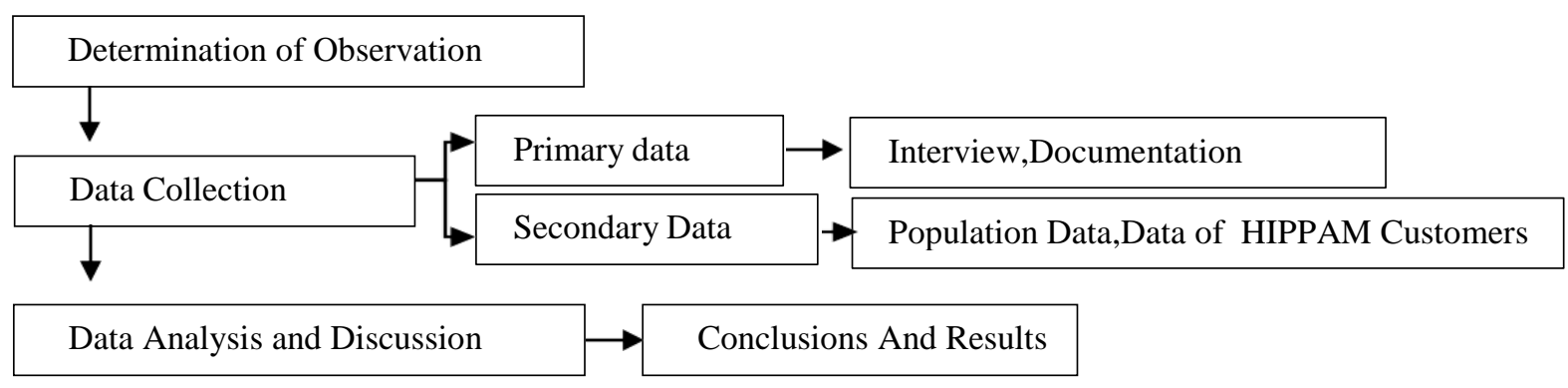

\subsection{Data Source}

Data sources are anything that can provide information about data. Based on the source, the data is divided into two, namely primary data and secondary data :

Primary data collection methods are as follows:

1. Observation Method

The location of a clean water source that is not far from the author's residence makes observations on the location and shape of the existing reservoir building optimal because it can be done repeatedly in order to get authentic and specific data.

2. Interview Method

The author also uses the interview method, namely by interviewing HIPPAM technical employees, in Campurrejo Village, Kec. Bojonegoro Kab. Bojonegoro.

Secondary data was obtained through various sources, namely literature, articles, and sites on the internet related to the research carried out. And archival data obtained from relevant agencies, as well as data - data that affect the research, among others:

1. Topographical Data

The topographic data used by the author here comes from a Google Earth map which contains regional contour data in Campurrejo Village district. Bojonegoro, Bojonegoro Regency.

2. Population Data

Population data is used to calculate the average population growth from year to year (Projection of the next 10 years) Source BPS (Central Statistics Agency) Bojonegoro

3. HIPPAM Customer Number Data

Data on the number of HIPPAM customers is used to calculate the average increase in HIPPAM subscribers per SR (house connection) from year to year. Source Chairman of HIPPAM, Campurrejo Makmur Village.

\subsection{Analysis Stage}

The data analysis technique used in this research is qualitative descriptive analysis. The data analyzed are:

1. Perform population projection analysis. This population projection analysis is carried out in order to find out how much population growth is estimated for the next 10 years (until 2031) so that the amount of water needed can be calculated. Residents of Campurrejo Village Bojonegoro The method used in population projection analysis is the Geometric method, Arimatic method, used and then the average value is taken.

2. Calculate the water needs that will be needed by the village community until the predicted year 2031. The calculated water needs in the Campurrejo village include Domestic water needs and Non-Domestic water needs. The calculation of this water demand refers to the clean water planning criteria for categories I, II, III, IV and V cities required by the Directorate General of Human Settlements of the Public Works Agency, 1996.

3. Analysis how much discharge is generated from water sources so that it can be supplied by the community of Campurrejo village, especially HIPPAM customers.Campurrejo Makmur. 


\section{Result and Discussion}

\subsection{Population Prediction}

Estimated population in Ds. Campurrejo was analyzed using 2 methods, namely the Geometric Method and the Arithmetic Method to obtain the accuracy of the population. Population data obtained from the Central Statistics Agency from 2017 to 2021, with predictions until 2031.

Table 5. Population data of Ds. Campurrejo district. Bojonegoro

\begin{tabular}{ccc}
\hline No & Year & Quantity \\
\hline 1 & 2017 & 5.472 \\
2 & 2018 & 5.266 \\
3 & 2019 & 5.780 \\
4 & 2020 & 5.856 \\
5 & 2021 & 6.085 \\
\hline \multicolumn{2}{l}{ Source: Central Bureau of Statistics of Bojonegoro Regency }
\end{tabular}

Selection of Methods Used With the correlation value (r) of the two methods, it can be determined the choice of the two methods for calculate service area projection up to 10 the coming year. Selection of the method based on the correlation coefficient (r) must be 1 or -1 or close to both values. (Permen PU No. 18 year 2007).

Table 6. Correlation Coefficient Results

\begin{tabular}{cc}
\hline Method & Coefficient Correlation \\
\hline Aritmatik & $-0,60$ \\
Geomatik & $-0,75$ \\
\hline \multicolumn{2}{c}{ Source: Calculation Results }
\end{tabular}

Table 7. Population Growth Geometry Selected Method

\begin{tabular}{cc} 
Year & Total population \\
\hline 2022 & 6156 \\
2023 & 6227 \\
2024 & 6299 \\
2025 & 6372 \\
2026 & 6446 \\
2027 & 6521 \\
2028 & 6597 \\
2029 & 6673 \\
2030 & 6751 \\
2031 & 6829 \\
\hline
\end{tabular}

Source: Calculation Results

From the analysis above, it is found that the population of Campurrejo Village in 2031 is 6829 people (10 years projection), then Campurrejo Village is included in the village category with a population ranging from $<20,000$ people. planning criteria of the Directorate General of Human Settlements of the Public Works Service, then:

a. Consumption of household connections: 70 liters/person/day.

b. General hydrant connection consumption is: 30 liters/person/day.

c. The comparison between household connections and public hydrants is: SR : HU $=70: 30$

\subsection{Clean Water Needs Analysis Domestic Sector}

a. Household Connection ( SR ) 
Table 8. Water Needs for Household Connections (SR)

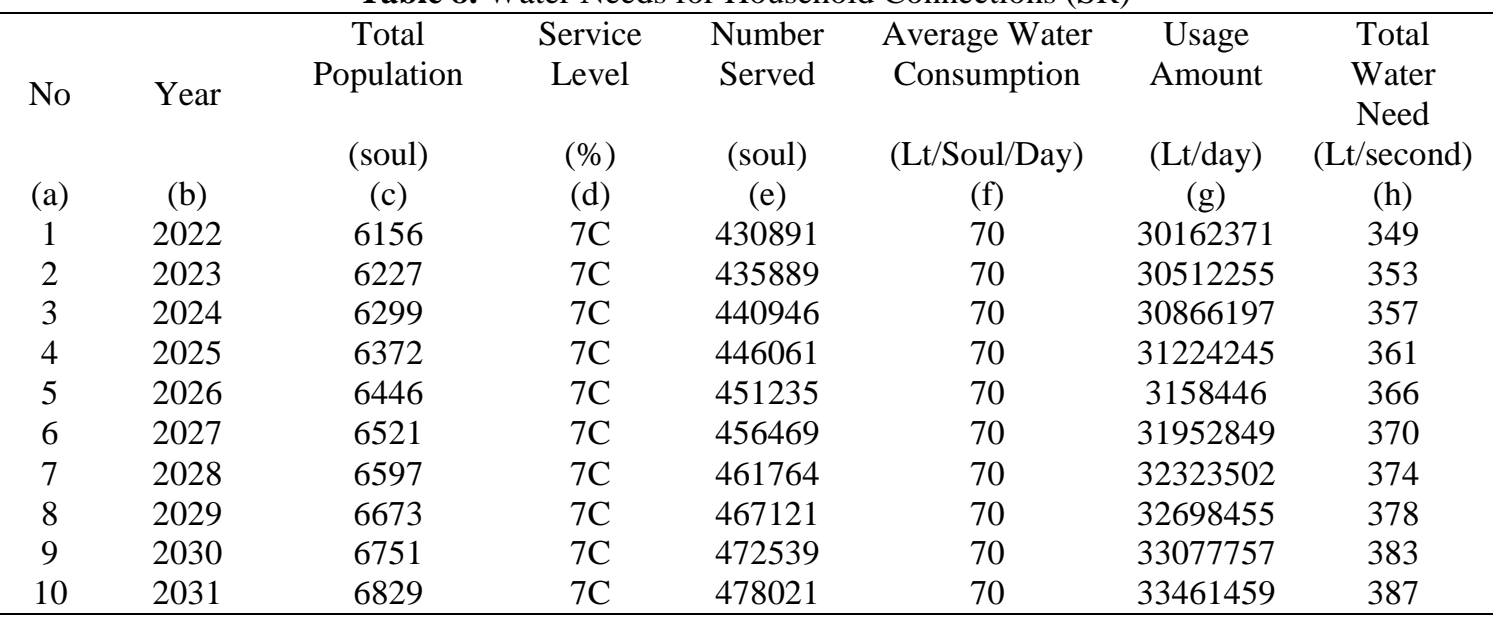

Source: Calculation Results

b. General Hydrant (HU)

Table 9. Water Needs for Public Hydrants (HU)

\begin{tabular}{cccccccc}
\hline No & Year & $\begin{array}{c}\text { Total } \\
\text { Population }\end{array}$ & $\begin{array}{c}\text { Service } \\
\text { Level }\end{array}$ & $\begin{array}{c}\text { Number } \\
\text { Served }\end{array}$ & $\begin{array}{c}\text { Average Water } \\
\text { Consumption }\end{array}$ & $\begin{array}{c}\text { Usage } \\
\text { Amount }\end{array}$ & $\begin{array}{c}\text { Total } \\
\text { Water } \\
\text { Need }\end{array}$ \\
\cline { 3 - 7 } & & $($ soul $)$ & $(\%)$ & $($ soul $)$ & (Lt/Soul/Day) & (Lt/day) & (Lt/second) \\
\hline (a) & (b) & $(\mathrm{c})$ & $(\mathrm{d})$ & $(\mathrm{e})$ & $(\mathrm{f})$ & $(\mathrm{g})$ & $(\mathrm{h})$ \\
1 & 2022 & 6156 & 30 & 184668 & 30 & 5540027 & 64 \\
2 & 2023 & 6227 & 30 & 186810 & 30 & 5604292 & 65 \\
3 & 2024 & 6299 & 30 & 188977 & 30 & 5669302 & 66 \\
4 & 2025 & 6372 & 30 & 191169 & 30 & 5735065 & 66 \\
5 & 2026 & 6446 & 30 & 193386 & 30 & 5801592 & 67 \\
6 & 2027 & 6521 & 30 & 195630 & 30 & 5868891 & 68 \\
7 & 2028 & 6597 & 30 & 197899 & 30 & 5936970 & 69 \\
8 & 2029 & 6673 & 30 & 200195 & 30 & 6005839 & 70 \\
9 & 2030 & 6751 & 30 & 202517 & 30 & 6075506 & 70 \\
10 & 2031 & 6829 & 30 & 204866 & 30 & 6145982 & 71 \\
\hline
\end{tabular}

Source: Calculation Results

\subsection{Clean Water Needs Analysis Non Domestic Sector}

a. Educational Facilities

Table 10. Water Demand for Educational Facilities

\begin{tabular}{|c|c|c|c|c|c|}
\hline No & Year & Student Number & $\begin{array}{l}\text { Average Water } \\
\text { Consumption }\end{array}$ & Usage Amount & Total Water Need \\
\hline & & (person) & ( Lt/Soul/Day ) & ( Lt/Day) & ( Lt/Second ) \\
\hline [a] & [b] & {$[\mathrm{c}]$} & [d] & {$[\mathrm{e}]$} & [f] \\
\hline 1 & 2022 & 5374 & 5 & 26868 & 0.311 \\
\hline 2 & 2023 & 5436 & 5 & 27180 & 0.315 \\
\hline 3 & 2024 & 5499 & 5 & 27495 & 0.318 \\
\hline 4 & 2025 & 5563 & 5 & 27814 & 0.322 \\
\hline 5 & 2026 & 5627 & 5 & 28137 & 0.326 \\
\hline 6 & 2027 & 5693 & 5 & 28463 & 0.329 \\
\hline 7 & 2028 & 5759 & 5 & 28793 & 0.333 \\
\hline 8 & 2029 & 5825 & 5 & 29127 & 0.337 \\
\hline 9 & 2030 & 5893 & 5 & 29465 & 0.341 \\
\hline 10 & 2031 & 5961 & 5 & 29807 & 0.345 \\
\hline
\end{tabular}

Source: Calculation Results 
b. Worship Facilities

Table 11. Water Needs for Mosque facilities

\begin{tabular}{cccccc}
\hline No & Year & Amount ( Unit ) & $\begin{array}{c}\text { Average Water Consumption } \\
\text { ( Lt/Unit/Day ) }\end{array}$ & $\begin{array}{c}\text { Usage Amount } \\
\text { ( Lt/day ) }\end{array}$ & $\begin{array}{c}\text { Total Water Need } \\
\text { ( Lt/Second ) }\end{array}$ \\
\hline$[\mathrm{a}]$ & {$[\mathrm{b}]$} & {$[\mathrm{c}]$} & {$[\mathrm{d}]$} & {$[\mathrm{e}]$} & {$[\mathrm{f}]$} \\
1 & 2022 & 4 & 3000 & 12000 & 0.139 \\
2 & 2023 & 4 & 3000 & 12000 & 0.139 \\
3 & 2024 & 4 & 3000 & 12000 & 0.139 \\
4 & 2025 & 4 & 3000 & 12000 & 0.139 \\
5 & 2026 & 4 & 3000 & 12000 & 0.139 \\
6 & 2027 & 5 & 3000 & 15000 & 0.174 \\
7 & 2028 & 5 & 3000 & 15000 & 0.174 \\
8 & 2029 & 5 & 3000 & 15000 & 0.174 \\
9 & 2030 & 5 & 3000 & 15000 & 0.174 \\
10 & 2031 & 5 & 3000 & 15000 & 0.174 \\
\hline
\end{tabular}

Source: Calculation Results

Table 12. Water Needs for Musholla facilities

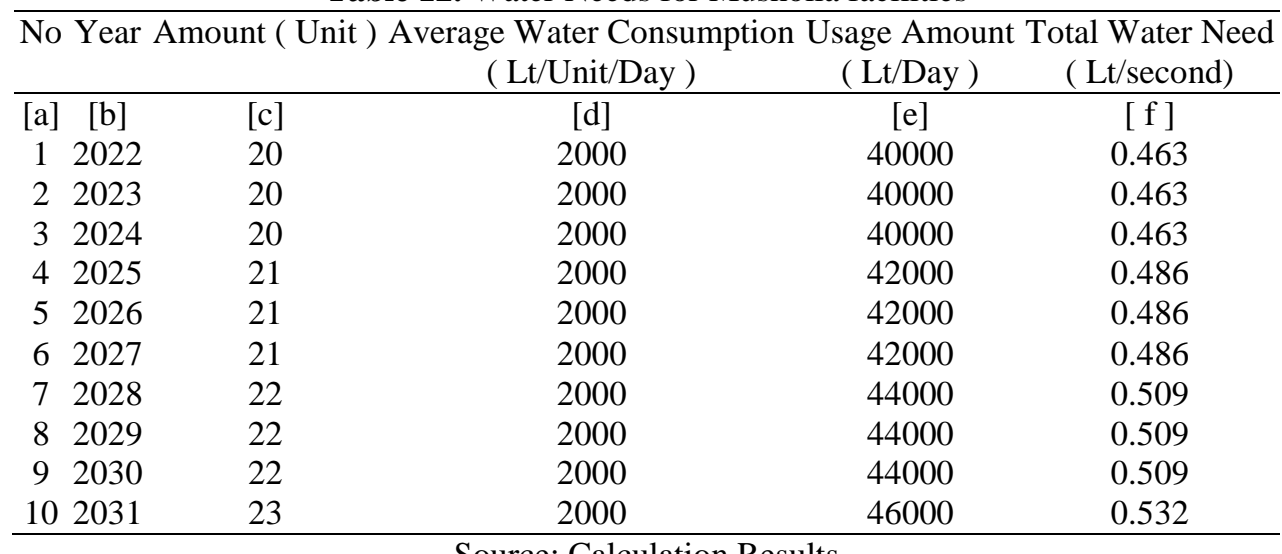

Source: Calculation Results

c. Market Facilities

Table 13. Water Demand for market facilities

\begin{tabular}{|c|c|c|c|c|c|c|}
\hline No Year & $\begin{array}{c}\text { Total } \\
\text { Population } \\
\text { (soul) }\end{array}$ & $\begin{array}{c}\text { Standard } \\
\text { requirement } \\
\text { ( } \mathrm{m} 2 / \text { Soul })\end{array}$ & $\begin{array}{c}\text { Broad } \\
\text { requirement } \\
(\mathrm{m} 2)\end{array}$ & $\begin{array}{l}\text { Average Water } \\
\text { Consumption } \\
\text { ( Lt/m2/Day ) }\end{array}$ & $\begin{array}{c}\text { Usage } \\
\text { Amount } \\
\text { ( Lt/Day ) }\end{array}$ & $\begin{array}{l}\text { Total Water } \\
\text { Need } \\
\text { ( Lt/Second ) }\end{array}$ \\
\hline [a] $[\mathrm{b}]$ & {$[\mathrm{c}]$} & {$[\mathrm{d}]$} & {$[\mathrm{e}]$} & {$[\mathrm{f}]$} & {$[\mathrm{g}]$} & {$[\mathrm{h}]$} \\
\hline 12022 & 6156 & $36000 / 120000$ & 1847 & 12000 & 22160110 & 256 \\
\hline 22023 & 6227 & $36000 / 120000$ & 1868 & 12000 & 22417167 & 259 \\
\hline 32024 & 6299 & $36000 / 120000$ & 1890 & 12000 & 22677206 & 262 \\
\hline 42025 & 6372 & $36000 / 120000$ & 1912 & 12000 & 22940262 & 266 \\
\hline 52026 & 6446 & $36000 / 120000$ & 1934 & 12000 & 23206369 & 269 \\
\hline 62027 & 6521 & $36000 / 120000$ & 1956 & 12000 & 23475563 & 272 \\
\hline 72028 & 6597 & $36000 / 120000$ & 1979 & 12000 & 23747879 & 275 \\
\hline 82029 & 6673 & $36000 / 120000$ & 2002 & 12000 & 24023354 & 278 \\
\hline 92030 & 6751 & $36000 / 120000$ & 2025 & 12000 & 24302025 & 281 \\
\hline 102031 & 6829 & $36000 / 120000$ & 2049 & 12000 & 24583929 & 285 \\
\hline
\end{tabular}

Source: Calculation Results 
d. Office and Shop Facilities

Table 14. Water Demand for Office Facilities

\begin{tabular}{cccccc}
\hline No & Year & $\begin{array}{c}\text { number of employes } \\
\text { ( person })\end{array}$ & $\begin{array}{c}\text { Average Water Consumption } \\
\text { (Lt/person/day) }\end{array}$ & $\begin{array}{c}\text { Usage Amount } \\
\text { ( Lt/day ) }\end{array}$ & $\begin{array}{c}\text { Total Water Need } \\
\text { ( Lt/second ) }\end{array}$ \\
\hline$[\mathrm{a}]$ & {$[\mathrm{b}]$} & {$[\mathrm{c}]$} & {$[\mathrm{d}]$} & {$[\mathrm{e}]$} & {$[\mathrm{f}]$} \\
1 & 2022 & 455 & 10 & 4552 & 0.053 \\
2 & 2023 & 461 & 10 & 4605 & 0.053 \\
3 & 2024 & 466 & 10 & 4658 & 0.054 \\
4 & 2025 & 471 & 10 & 4712 & 0.055 \\
5 & 2026 & 477 & 10 & 4767 & 0.055 \\
6 & 2027 & 482 & 10 & 4822 & 0.056 \\
7 & 2028 & 488 & 10 & 4878 & 0.056 \\
8 & 2029 & 493 & 10 & 4935 & 0.057 \\
9 & 2030 & 499 & 10 & 4992 & 0.058 \\
10 & 2031 & 505 & 10 & 5050 & 0.058 \\
\hline
\end{tabular}

Source: Calculation Results

Table 15. Water Demand for Shopping Facilities

\begin{tabular}{cccccc}
\hline No & Year & $\begin{array}{c}\text { number of employes } \\
\text { ( person })\end{array}$ & $\begin{array}{c}\text { Average Water Consumption } \\
\text { (Lt/person/day) }\end{array}$ & $\begin{array}{c}\text { Usage Amount } \\
\text { ( Lt/day ) }\end{array}$ & $\begin{array}{c}\text { Total Water Need } \\
\text { ( Lt/second ) }\end{array}$ \\
\hline$[\mathrm{a}]$ & {$[\mathrm{b}]$} & {$[\mathrm{c}]$} & {$[\mathrm{d}]$} & {$[\mathrm{e}]$} & {$[\mathrm{f}]$} \\
1 & 2022 & 202 & 10 & 2023 & 0.023 \\
2 & 2023 & 205 & 10 & 2047 & 0.024 \\
3 & 2024 & 207 & 10 & 2070 & 0.024 \\
4 & 2025 & 209 & 10 & 2094 & 0.024 \\
5 & 2026 & 212 & 10 & 2119 & 0.025 \\
6 & 2027 & 214 & 10 & 2143 & 0.025 \\
7 & 2028 & 217 & 10 & 2168 & 0.025 \\
8 & 2029 & 219 & 10 & 2193 & 0.025 \\
9 & 2030 & 222 & 10 & 2219 & 0.026 \\
10 & 2031 & 224 & 10 & 2244 & 0.026 \\
\hline
\end{tabular}

Source: Calculation Results

e. Health Center Facilities

Table 16. Water Needs for Health Center Facilities

\begin{tabular}{cccccc}
\hline No & Year & Amount & $\begin{array}{c}\text { Average Water } \\
\text { Consumption } \\
\text { (Lt/unit/day) }\end{array}$ & $\begin{array}{c}\text { Usage Amount } \\
\text { ( Lt/day ) }\end{array}$ & Total Water Need \\
\hline$[\mathrm{a}]$ & {$[\mathrm{b}]$} & {$[\mathrm{ct} / \mathrm{second})$} \\
\hline & 2022 & 1 & {$[\mathrm{~d}]$} & {$[\mathrm{e}]$} & 0.014 \\
2 & 2023 & 1 & 1200 & 1200 & 0.014 \\
3 & 2024 & 1 & 1200 & 1200 & 0.014 \\
4 & 2025 & 1 & 1200 & 1200 & 0.014 \\
5 & 2026 & 1 & 1200 & 1200 & 0.014 \\
6 & 2027 & 1 & 1200 & 1200 & 0.014 \\
7 & 2028 & 1 & 1200 & 1200 & 0.014 \\
8 & 2029 & 1 & 1200 & 1200 & 0.014 \\
9 & 2030 & 1 & 1200 & 1200 & 0.014 \\
10 & 2031 & 1 & 1200 & 1200 & 0.014 \\
\hline
\end{tabular}

Source: Calculation Results

From the calculations above, it is known that the clean water needs of Campurrejo Village in 2031 according to the predicted population is 1.105 liters/second, the maximum daily need is 1.326 liters/second, and the water needs at peak hours are 1.768 liters/second.

\subsection{Prediction of water demand for HIPPAM customers in 2031}

a. Prediction of customer HIPPAM in 2031 
The prediction of clean water needs in 2031 is calculated referring to the predicted increase in customers HIPPAM Campurrejo Makmur or home connection.

Table 17. Prediction of customer HIPPAM

\begin{tabular}{ccc}
\hline No. & Year & Amount (SR) \\
\hline 1 & 2022 & 41 \\
2 & 2023 & 61 \\
3 & 2024 & 89 \\
4 & 2025 & 131 \\
5 & 2026 & 192 \\
6 & 2027 & 283 \\
7 & 2028 & 415 \\
8 & 2029 & 611 \\
9 & 2030 & 897 \\
10 & 2031 & 1298 \\
\hline
\end{tabular}

Predicted customers of HIPPAM “Campurrejo Makmur” Bojonegoro in 2031 is 1298 SR (house connection)

b. Analysis Water Needs HIPPAM Customer

Calculation of clean water needs based on the prediction of the number of customers, HIPPAM house connection (SR) obtained the following results.

Table 18. Water Demand Discharge

\begin{tabular}{cccc}
\hline No. & Year & Amount (SR) & Q (lt/second) \\
\hline 1 & 2022 & 41 & 0.5 \\
2 & 2023 & 61 & 0.76 \\
3 & 2024 & 89 & 1.11 \\
4 & 2025 & 131 & 1.64 \\
5 & 2026 & 192 & 2.40 \\
6 & 2027 & 283 & 3.54 \\
7 & 2028 & 415 & 5.19 \\
8 & 2029 & 611 & 7.64 \\
9 & 2030 & 897 & 11.21 \\
10 & 2031 & 1298 & 16.23 \\
\hline \multicolumn{4}{c}{}
\end{tabular}

c. Analysis Drilling Well Water Source Discharge HIPPAM

Table 19. water source discharge

\begin{tabular}{cccccc}
\hline No. & Year & $\begin{array}{c}\text { Q Water Needs } \\
\text { (lt/Second) }\end{array}$ & $\begin{array}{c}\text { source capacity } \\
\text { (lt/Second) }\end{array}$ & $\begin{array}{c}\text { production capacity } \\
\text { (lt/Second) }\end{array}$ & $\begin{array}{c}\text { production shortage } \\
(\text { lt/Second) }\end{array}$ \\
\hline 1 & 2022 & 0.5 & 5.0 & 5.0 & - \\
2 & 2023 & 0.76 & 5.0 & 5.0 & - \\
3 & 2024 & 1.11 & 5.0 & 5.0 & - \\
4 & 2025 & 1.64 & 5.0 & 5.0 & - \\
5 & 2026 & 2.40 & 5.0 & 5.0 & - \\
6 & 2027 & 3.54 & 5.0 & 5.0 & 0.19 \\
7 & 2028 & 5.19 & 5.0 & 5.0 & 2.64 \\
8 & 2029 & 7.64 & 5.0 & 5.0 & 6.21 \\
9 & 2030 & 11.21 & 5.0 & 5.0 & 11.23 \\
10 & 2031 & 16.23 & 5.0 & 5.0 & \\
\hline
\end{tabular}

Source: Calculation Results

The discharge capacity of the HIPPAM bore well is still sufficient. Production capacity/pump discharge from 2022 to 2027 can meet the clean water needs of the HIPPAM "Campurrejo Makmur" unit, but from 2028 onwards the deep well pump discharge is no longer able to meet water needs. 


\section{Conclusion And Suggestions}

\subsection{Conclusion}

From the results of the calculation of the analysis of clean water needs in Campurrejo Village, the following conclusions can be drawn:

1. Clean water needs of Campurrejo Village in 2031 whose population is analyzed using Geometric formulas with a total of 6,829 From the above calculation, it is known that the clean water needs of Campurrejo Village in 2031 according to the predicted population is 1,105 liters/second, the maximum daily requirement is 1,326 liters /second, the water demand at peak hours is 1.768 liters/second. And from the calculation of the clean water needs of Campurrejo Village in 2031 according to the prediction of the number of HIPPAM customers is 1.623 liters/second, the maximum daily need is 1.948 liters/second, and the water demand at peak hours is 2.567 liters /second.

2. Prediction of the number of customers of HIPPAM "Campurrejo Makmur" in 2031 is 1298 SR Reservoir capacity needs to meet clean water needs in 2031 is $139 \mathrm{~m} 3$

It is advisable to conduct a review of the reservoir capacity in the village of Campurrejo Makmur so that the prediction of water demand due to the increase in population and HIPPAM customers can be fulfilled. Considering that raw water for clean water is decreasing day by day, it is hoped that its use is as good as possible according to needs. In order to obtain an optimal service system, it is necessary to build clean water supply facilities.

\section{References}

Anonymous. 1998. Technical Guidelines for Planning, Master Plans for Systems, Urban Water Supply Systems. Department of Public Works, Directorate General of Human Settlements.

Anonymous. 1998. Practical Guidelines for Rural Water Supply System Development. Department of Public Works, Directorate General of Human Settlements.

Bojonegoro Regency Central Bureau of Statistics. 2017; 2018; 2019; 2020; 2021.Bojonegoro in Figures 2017; 2018; 2019; 2020; 2021 Bojonegoro Regency. Bojonegoro

Moegijantoro. 1996. Water Needs. PT Empat Sekawan: Surabaya.

Reksa. 2020. Analysis of Clean Water Needs at Muhammadiyah Hospital Palembang. Faculty of Civil Engineering, University of Palembang.

SK-SNI for Clean Water. 1990. 